\title{
軽量形鋼はりとコンクリートスラブの 合成効果に関する実験
}

$\begin{array}{rrrrr}\text { 正会員 } & \text { 仲 } & & \text { 威 } & \text { 雄* } \\ \text { 同 } & \text { 藤 } & \text { 本 } & \text { 盛 } & \text { 人** } \\ \text { 同 } & \text { ○杉 } & \text { 山 } & \text { 圭 } & \text { 二*** }\end{array}$

\section{1. 実験の目的と概要}

鉄骨構造物で、鉄骨はりにコンクリートスラブ の構法は通常用いられる。このような場合、鉄骨 はりとコンクリートスラブのズレをなんらかの方 法でとめ、はりとスラブとの協力性、いわ沟る合 成効果が期待できれば、鉄骨はりは剛性の増加と ともに非常に経済的な設計が得られる。

このととは土木関係の道路橋で鉄材の節約、は りせいの減少などの目的から、合成桁 ${ }^{1)}$ として研 究成果をあげて㧍り、建築関係でも合成効果に関 する研究2)が発表されている。建築で用いられる 通常の鉄骨はりは、土木関係のそれに比較して剛 性が少いため、どの程度の合成効果が得られるか 問題である。

そこでこの研究は鉄骨はりとして、比較的はり せいの少い軽量形鋼 $2 \mathrm{C}-150 \times 65 \times 20 \times 3.2 、 2 \mathrm{C}$ $100 \times 50 \times 20 \times 3.2$ の 2 種を選び、スパン 3.000 $\mathrm{m} 、$ コンクリートスラブとして、厚さ $90 \mathrm{~mm}$ (ス ラブ配筋)、币 $750 \mathrm{~mm}(1 / 4$ スパン)、ズレ止め はすべて折曲筋 $(9 \phi)$ を用い、鉛直荷重を作用さ せたときのはりのたわけ、応力度分布、応力度 分布からの中立軸を調查し、スラブが全断面有効 に協力したと考えたときの計算值と比較検討し、 軽量形鋼はりとコンクリートスラブの合成効果を 実験的に研究するものである。こてではりに協力 するスラブ巾（有効巾）が問題であるがこの研究 では一応 $1 / 4$ スパンとした。

\section{2. 試験体と実験方法}

\section{1 試験体}

予備実験、本実験に用いたコンクリートスラブは、第 1.1 図に示すように、愿さ $90 \mathrm{~mm}$ 、巾 $1 / 4$ スパン $=750$ $\mathrm{mm} 、$ スパン $3.000 \mathrm{~m}$ で、配筋は $9 \phi$ 筋をスラブ配筋 とした。コンクリートはポルトランドセメント（イワキ セメント）を用い、設計強度 $150 \mathrm{~kg} / \mathrm{cm}^{2}$ 、調合は JASS 5 により室内にて、機械練り現場打ちとし、養生は散水 などにより温度一定とした。調合を第 1 表に示す。各試 験体とも仮枠は 3 週目に除去した。

\footnotetext{
* 東京大学教授 工博 **東京工業大学助教授 工博 *** 社団法人日本軽量鉄骨建築協会研究課
}

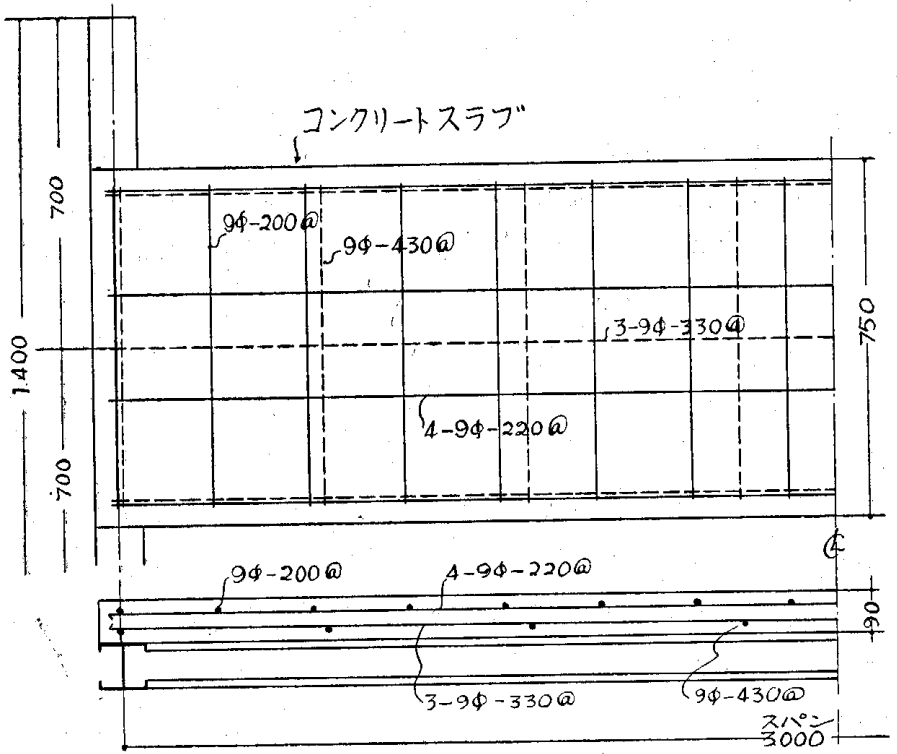

1.1 図

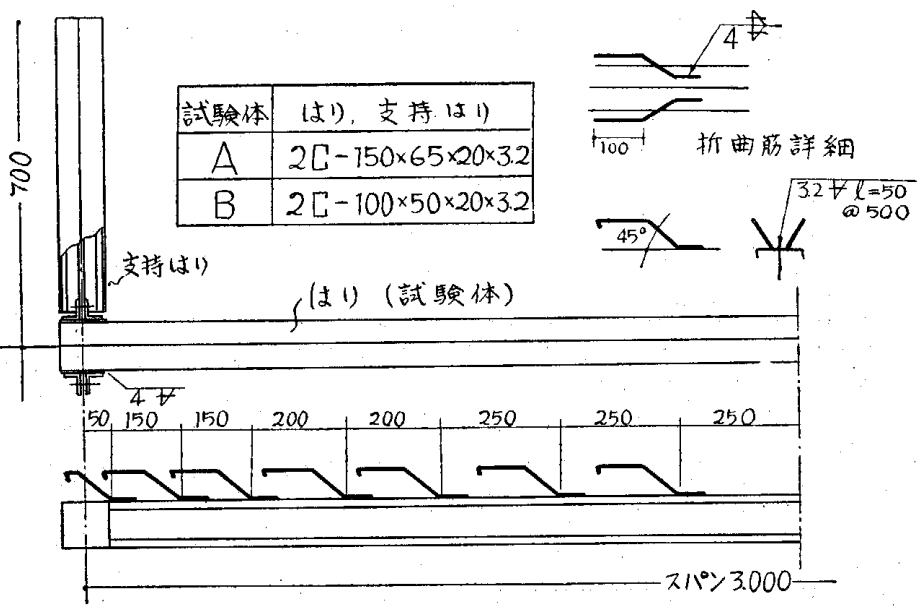

第 1.2 図

第 1 表

\begin{tabular}{|c|c|c|c|c|c|c|}
\hline $\begin{array}{l}\text { 設計強席 } \\
\mathbf{k g} / \mathrm{cm}^{2}\end{array}$ & 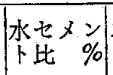 & $\mid \begin{array}{c}\text { スランプ } \\
\mathrm{cm}\end{array}$ & $\begin{array}{l}\text { 有效水量 } \\
\mathbf{k g} / \mathbf{m}^{3}\end{array}$ & $\begin{array}{c}\text { セx/ } \\
\mathrm{kg} / \mathrm{m}^{3}\end{array}$ & $\begin{array}{c}\begin{array}{c}\text { 砂 } \\
\mathrm{kg} / \mathrm{m}^{3}\end{array} \\
\end{array}$ & $\begin{array}{l}\text { 砂利 } \\
\mathbf{k g} / \mathbf{m}^{3}\end{array}$ \\
\hline 150 & 67 & 19 & 193 & 288 & 871 & 1055 \\
\hline
\end{tabular}

鉄骨はりは第 1.2 図に示すように、2C- $150 \times 65 \times 20$ $\times 3.2($ 試験体 A) 、 2 C $-100 \times 50 \times 20 \times 3.2$ (武験体 B) を計画した。

ここでズレ止めについては折曲筋の形成を用い詳細を 第 1.2 図に示した。 
第 2 図より 1 本の折曲筋汇働く引張力 $D$ は (1)式で 求まり、はりは単純支持、スラブは全断面有効として最 大荷重 $1000 \mathrm{~kg} / \mathrm{m}^{2}$ で、折曲筋 $9 \phi$ として間隔 $a$ を定め た。

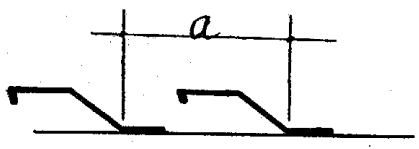

第 2 図

$$
\left.\begin{array}{l}
D=\frac{T \cdot a}{\cos \alpha} \\
T=\frac{Q \cdot G_{C}}{I_{V}}
\end{array}\right\}
$$

$D:$ 鉄筋に働く引張力 $\mathrm{kg}$

$T:$ 接触面の単位長に働くせん断力 $\mathrm{kg} / \mathrm{cm}$

$a:$ 折曲筋の間隔 $\mathrm{cm}$

$\alpha:$ 折曲筋の角度

$Q:$ はりに作用するせん断力 $\mathrm{kg}$

$G_{C}:$ 合成はり断面の中立軸に関するスラブの断面 1 次モーメント $\mathrm{cm}^{3}$

$I_{V}:$ 合成はり断面の中立軸に関する断面 2 次モーメ ント $\mathrm{cm}^{4}$

\section{2 実験方法}

合成はりとしての本実験を行うま光に、予備実験とし てコンクリートスラブだけの曲げ剛性を確めるため、両 端単純支持の本実験と同ビスラブだけの試験体でコンク リート打ち後 4 週目に載荷し、荷重と $1 / 2$ スパン点のた わみを求めた。

本実験は試験体A、B とも第 3 図に示すように、25 丸鋼にて単純支持として、コンクリート打ち後 4 週目に 等分布載荷した。荷重としては $30 \mathrm{~cm} \times 40 \mathrm{~cm}$ の布袋に 絶乾の砂をつめ $6 \mathrm{~kg} /$ 袋、 $12 \mathrm{~kg} /$ 袋を作り、50 kg/m² $100 \mathrm{~kg} / \mathrm{m}^{2}$ の荷重とした。乙れは試験体の変位変形を拘 束せずに等分布載荷ができるようにしたものである。

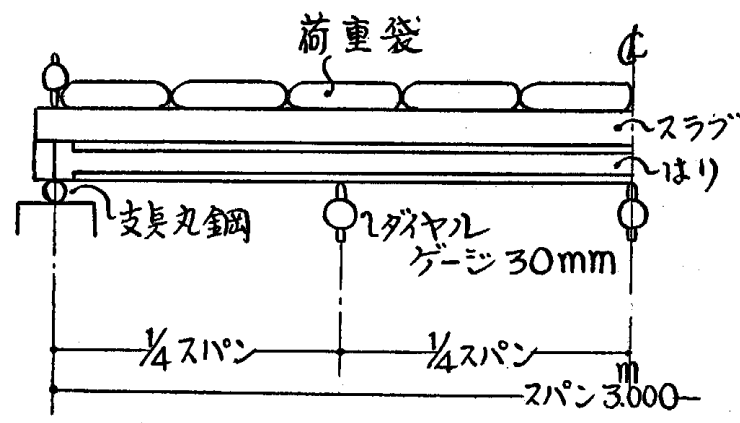

第 3 図

実験は上記の方法で載荷したが、試験体の変位測定は 支点、 $1 / 4$ スパン点、 $1 / 2$ スパン点に設置した $30 \mathrm{~mm}$ ダ イヤルゲージにより（第 3 図）、応力度測定は $1 / 4$ スパ ン点、1/2 スパン点に貼付した W.S.Gによった。W.S. Gの貼付個兹、枚数を第 4 図に示す。

\section{3. 実験結果}

\section{1 予備実験の結果}

コンクリートスラブのみの曲げ剛性を確めるための予 備実験では、1/2 スパン点のたわみのみを測定したが、
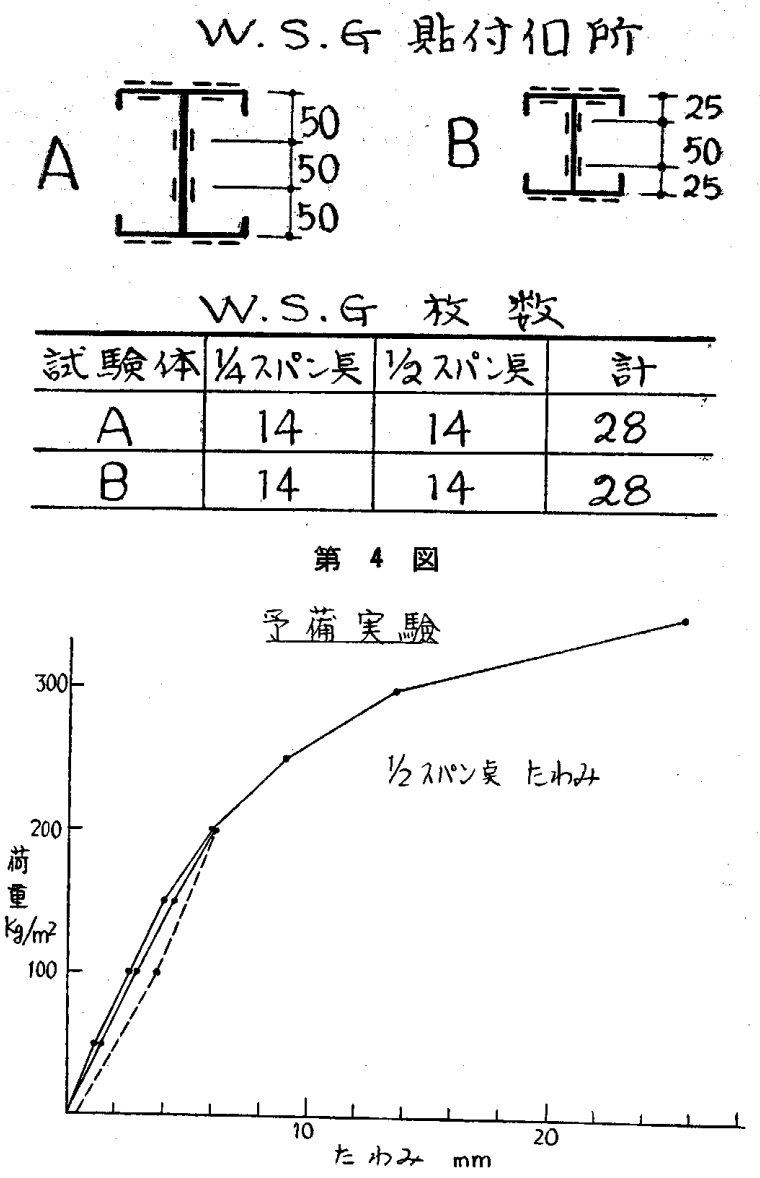

第 5 図

この荷重とたわみの関係を第 5 図に示す。

\section{2 本実験の結果}

予備実験よりコンクリートスラブ単体の曲げ剛性を求 め得たので、引きつづき合成はりとしての本実験を行。 た。

a) コンクリート強度、弾性係数

各試験体ともコンクリートスラブのテストピースの強 度実験より、マルテンスミラーで弾性係数を求めた。破 壊強度、弾性係数を第 2 表に示す。

\begin{tabular}{|c|c|c|c|c|}
\hline 試験体 & No & 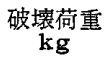 & $\begin{array}{l}\text { 破壞強度 } \\
\mathbf{k g} / \mathrm{cm}^{2}\end{array}$ & $\begin{array}{c}\text { 弾性係数 } \\
\times \times 10^{5}\end{array}$ \\
\hline \multirow{4}{*}{ A } & 1 & 30.5 & & 2.49 \\
\hline & 2 & 30.9 & & 2.15 \\
\hline & 3 & 26.4 & & 2.35 \\
\hline & 平均 & 29.3 & 166 & 2.33 \\
\hline \multirow{4}{*}{ B } & 1 & 30.0 & & 2.17 \\
\hline & 2 & 27.0 & & 2.08 \\
\hline & 3 & 30.5 & & 2.02 \\
\hline & 平均 & 29.2 & 165 & 2.09 \\
\hline
\end{tabular}

第 2 表

b）荷重たわけ曲線

各試験の荷重とたわみの関係のうち、1/2 スパン点の たわみを第 $6.1 〜 6.2$ 図に示す。

c）荷重応力度曲線

备試験体各点の荷重と応力度の関係のうち、1例とし て1/2 スパン点の外縁部についての応力度を、第 7.1〜 


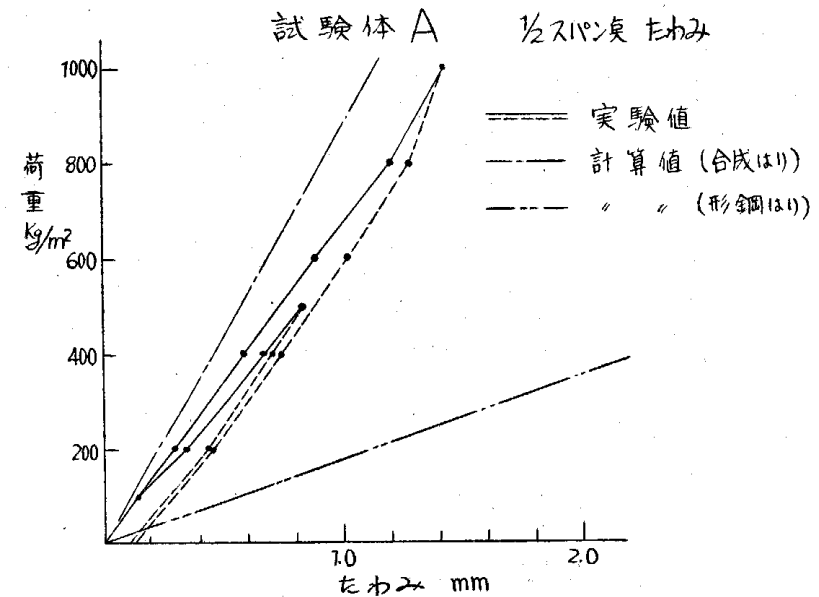

第 6.1 図

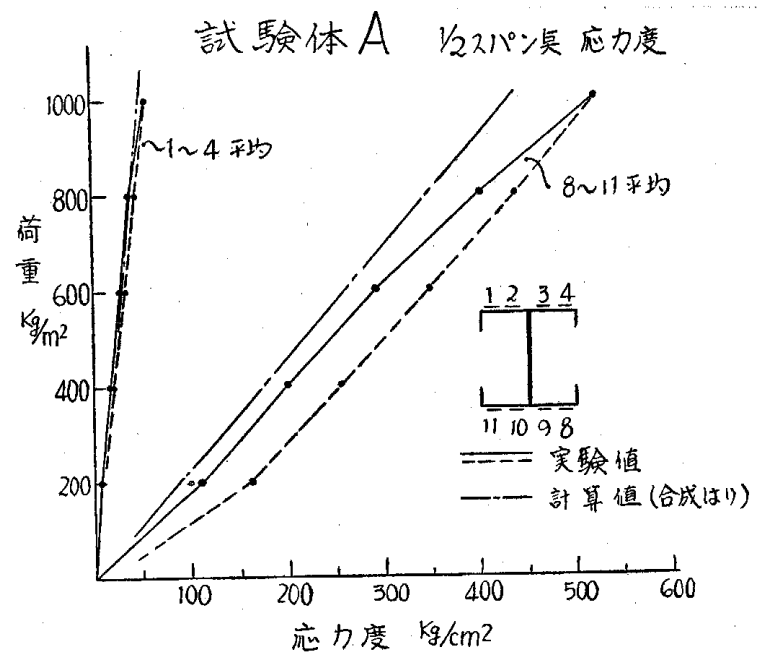

第 7.1 図

7.2 図に示す。

\section{4. 結果の考察}

a）各武験体とも第 6.1 6.2 図に示すように、たわ みは直線的変化を示し、鉄骨はりの計算值より遥かに合 成はりの計算值に近く、合成效果を表わしている。

b）応力度についても第 7.1 7.2 図から明らかなよ うに、直線的変化を示し、合成はりの計算值に近く合成 効果を充分に表わしている。

c）ある荷重時におけるはり断面内の各点の応力度の 調查から、乙れらを結ぶと略直線となり、これによって その荷重時の中立軸が得られる。との荷重と中立軸の関 係を示したものか第 8.1 8.2 図である。これから明ら

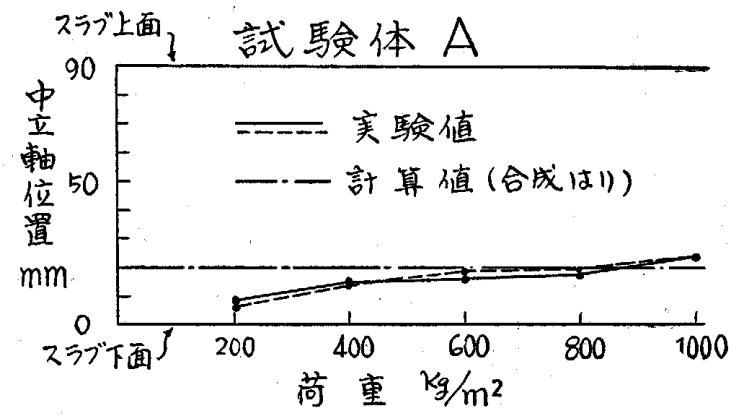

第 8.1 図

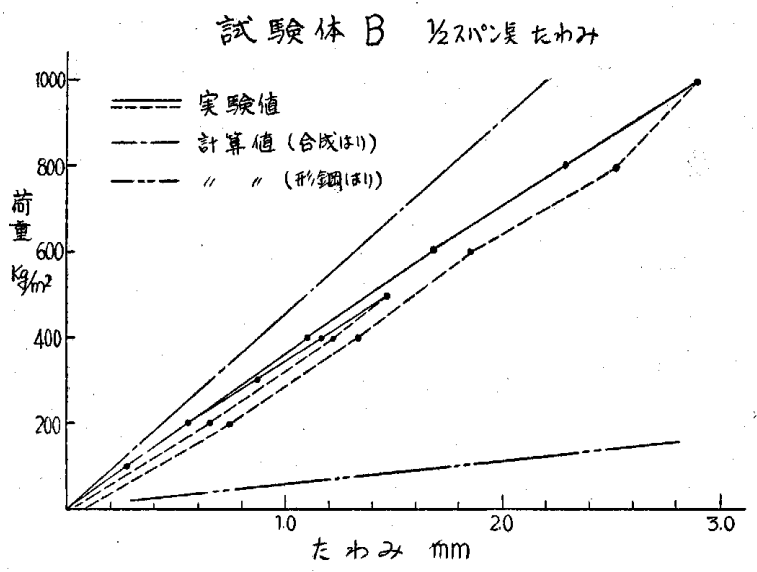

第 6.2 図

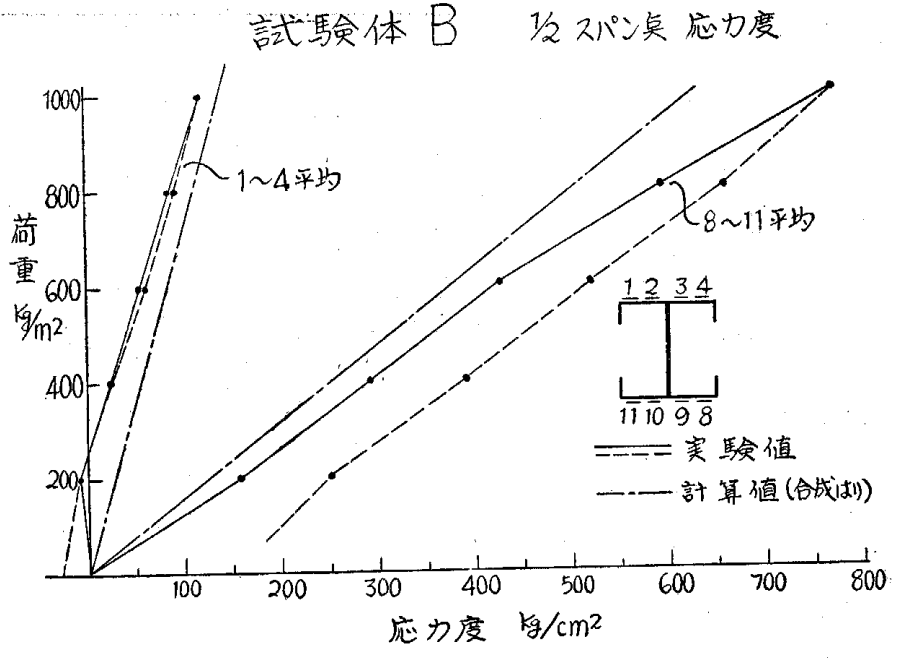

第 7.2 図

かなように、試験体 $\mathrm{A} 、 \mathrm{~B}$ とも実験值からの中立軸は荷 重の増加とともに、計算值に近づき略一定となる。その 位置はスラブ下端より上方略 $20 \mathrm{~mm}$ で、計算值は試験 体 $\mathrm{A}: 20.7 \mathrm{~mm}$ 、試験体 $\mathrm{B}: 28.7 \mathrm{~mm}$ である。

d）荷重とたわみ、応力度、および中立軸の位置の関 係からほぼ合成効果は期待できるが、これらはいづれも 計算值より多少おちている。てれはズレ止めの効果が多 少おちるてとのためであり、ズレ止め設計には余裕をも たすべきである。

e）なおてのように設計したズレ止めを設けても、は りに協力するコンクリートスラブの币（有効巾）には適 度があり、建築における有効巾の問題はズレ止めとも関

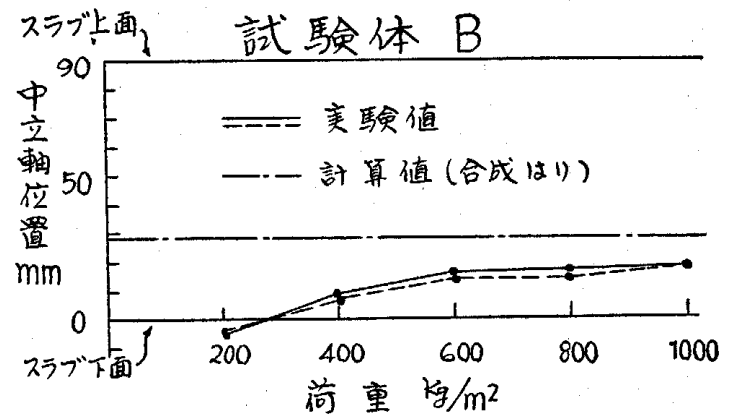

第 8.2 図 
係して研究すべきことである。またての実験では試験体 $\mathrm{A} 、 \mathrm{~B}$ ともコクリート強度は同に゙設計し、弾性係数 もほぼ等しかったが、コンクリート強度も合成効果に影 響を及ぼすことが考觉られる。

\section{5. むす び}

a）鉄骨構造物のなかで比較的はりせいの小さい軽量 形鋼はりでも、適当なズレ止めを用いれぱ充分合成効果 は期待できる。

b）はりに協力し剛性を増加さすスラブの有効巾につ いては、種々研究されてはいるが、今後コンクリート強 度、ズレ止めなどと関係して、実験的に研究すべきであ る。 c） コンクリートのクリープによる合成効果への影響 も明らかにすべきである。

おわりに

この研究は昭和 32 年度文部省科学試験研究費、総合 研究によった。実験およびデータ整理に尽力された東京 工業大学学生、池本智汎君、小川健君、奈須野清君、ま た試験体製作に御協力下さった巴組鉄工所および清水工 務店に感謝致します。

\section{[参考文献]}

1) 安宅 勝: 合成桁

2）鶴田明、国場幸一郎：軽量 C形鋼梁と床版の協力性につ いて日本建築学会論文報告集 No. 57 昭和 32 年 7 月 